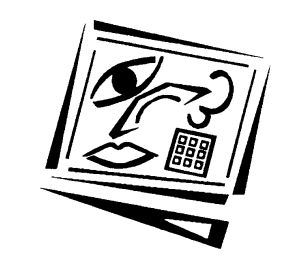

\title{
A study on the adoption of clickers in higher education
}

\author{
Kumar Laxman \\ Nanyang Technological University
}

\begin{abstract}
Audience response systems or 'clickers' are being used widely in both large and small educational settings. Clickers leverage upon a number of technological affordances to allow for adaptive and flexible learning to be accomplished. To promote active learning in its classrooms, Nanyang Technological University (NTU) in Singapore rolled out a campus-wide initiative called "Learning that Clicks!" on using the interactive technology of clickers. This initiative will enable the necessary transformation of pedagogy and learning design to support the epistemological paradigm shift of becoming more student-centric in nature. This preliminary study attempted to investigate the experiences of undergraduate students in learning in clicker-supported instructional environments. A survey consisting of nine items was administered to 640 students from 12 classes in the Engineering, Humanities and Sciences schools to solicit their views on the effectiveness of clicker technology as an instructional device. Generally, students felt that the use of clickers has improved the quality of their learning experiences. Overall, this study reveals that clicker technology offers great promise in promoting more collaborative and engaging learning environments and innovating instructional delivery, provided lecturers apply sound pedagogical principles in their teaching.
\end{abstract}

\section{Background of study}

The Blue Ribbon Commission (BRC) was convened in August 2007 to review all aspects of undergraduate education at Nanyang Technological University (NTU), Singapore. The review was conducted in light of the global conditions faced by Singapore in the twenty-first century and preparing its students for the challenges of this new era. The key elements of the holistic framework developed by BRC focused on five interrelated and mutually reinforcing attributes: moral character, disciplinary depth and life-long learning, creativity and innovation, leadership and teamwork, and professionalism and public service. The philosophical underpinnings of this framework are based on the observations that the traditional passive learning paradigm of information delivery by the lecturer to his students is no longer adequate for adept functioning in a knowledge-based economy. Technological advancements have produced a new generation of student learners who are savvy in using technology to meet their needs. In fully harnessing and optimising the talents of this new cohort of students a paradigmatic shift to active learning supported by cuttingedge technologies is needed - an educational approach that focuses on self-directed learning with emphasis on active inquiry, application and synthesis of information and autonomous learning. In response to this philosophical intent of NTU to promote active learning at an institution-wide level, a number of pedagogical initiatives have been proposed and implemented to foster student-centric curricular design and enable its students to become critical learners and researchers. 
One of the campus-wide initiatives that was rolled out was "Learning that Clicks!" [http://clickers.ntu.edu.sg/] - the innovative use of the interactive instructional technology of 'clickers' (or 'audience response systems', or 'personal response systems', or 'electronic voting systems'). This initiative was designed to enable the necessary transformation of pedagogy to reflect the student-centred, digitally driven learning styles of current and subsequent generation/s of learners. More importantly, this initiative will assist in the promotion of active learning experiences of students without radically altering existing physical classroom facilities (Gan, 2011). This project will also enable faculty at NTU to achieve the desired goal of "teach less and learn more" where lecturers are encouraged to teach less expository content information and instead facilitate their students' active participation in the learning process.

As a result of this initiative, 95\% of lecture theatres, tutorial rooms and seminar rooms in NTU's different schools have been equipped progressively with clicker technology [https:/ / compass.ntu.edu.sg/resources/Pages/Clickers.aspx\#benefits]. The lecture theatres were of particular interest as it was envisaged that this technology has the potential to transform the current one-way, teacher-directed information transmission model dominating NTU's lecture experiences. About 150 undergraduate courses have been reported to have used clickers in classroom teaching. The size of a credit-card, clickers provide students with a 'cool' factor in handling the devices as well as support the creation of interactive engagement in large lecture theatres and smaller classrooms. Initial training was provided on a large scale to faculty to familiarise them with the technical features of clickers and procedures for managing the technology in the teaching facilities. This has been made easier by the fact that the technology is user friendly and simple to operate. About 300 faculty (about 10\% of total faculty strength) have attended these training sessions thus far. All undergraduate students were issued clickers free of charge but they have to purchase replacements at subsidised rates if they lose or damage them.

\section{Research context and rationale of study}

This baseline study was designed to examine NTU students' perspectives on the usefulness of the clicker technology in facilitating educational approaches that actively engage students in their own learning. Though in recent times considerable interest has been expressed in wanting to explore the instructional potential of clickers, few scholarly sources on the impact of using clickers in classrooms in institutions of higher learning exist (Moreau, 2009). Little research has been conducted, particularly in relation to student experiences of using clickers and their perceptions as to why clickers are beneficial to the learning of these learners. Much of what is written about clicker technology is focused on formal outcomes such as academic learning gains and retention. For example, Campbell and Mayer (2009) note that clickers can enhance the learning performance of students in class. Lin, Liu and Chu (2011) found in their study on clicker-assisted conceptual change that students in the experimental group who used clickers outperformed in a comprehension test students in a control group where normal instructional methods were used.

However, as mentioned earlier, much less is known about the lived experiences of students in using the clicker technology in the classrooms (MacArthur, 2010). Penuel, Roschelle, Crawford, Shechtman \& Abrahamson (2004) mentioned that the effects of interactive pedagogies and technologies need to be tested and measured through the implementation of appropriate research design studies - something which they argue 
is currently lacking in practice. Besides detailing the aspects of the research study that was carried out in NTU to ascertain students' experiences of the utility of clickers in increasing learning, this paper will also contribute to the limited existing research corpus on the Asian perspectives of the use of clickers in institutions of higher learning.

\section{Overview of the literature}

\section{Clickers and their usage}

Audience response systems are being used widely in both large and small educational institutional settings (Caldwell, 2007). These handheld devices are commonly called "clickers" or "key-pads" in the United States and "handsets" or "zappers" in the United Kingdom. The term "clickers" will be used throughout this article to maintain consistency in writing. Clickers are small transmitters that students utilise to transmit their responses by pressing appropriate buttons (Simpson \& Oliver, 2006). Usually clickers come with a 10-digit numeric keypad and some accessory buttons such as a power switch, a send button or function keys that permit text entry (Barber \& Njus, 2007).

Modern clickers leverage upon a number of technological affordances to allow for adaptive and flexible learning. The first is that clickers are wireless handsets with each unit possessing a unique signal to enable responses from each individual student to be identified and recorded (Caldwell, 2007). The next key component embedded in clicker technology is the linking to data manipulation and a projection display. Responses from students can be displayed on the projection screen instantly as bar charts or in other appropriate formats. The ability to tabulate and display the collective data to the entire class is an important feature. This provision of immediate display of results enables the lecturer to easily assess students' understanding of material covered in class and offer remedial instructions to correct student misunderstandings, if any. Students also obtain prompt feedback on how well they are learning. The third and final component is a personal computer loaded with the software that facilitates the collection, processing, display and storage of response data. This software is usually the component most staff have to use to operate clicker technology (Caldwell, 2007). Overall, Parsons (2005) notes that though clicker technological hardware may sound complex, most clicker systems are relatively easy to use with only an "intermediate" level of computer skills needed, thereby freeing the instructor from technical operations and and allowing concentration on pedagogical delivery.

Instructors have reported the use of clickers in classes ranging from 15 students (Draper, 2002) to more than 200 students (Cue, 1998). These findings buttress the argument that clicker technology can effectively support both small and large groups teaching. Clicker technology has been incorporated in a wide ranging number of courses spanning across different disciplinary fields of expertise such as nursing (Halloran, 1995), communication (Jackson \& Trees, 2003), computer science (Draper, 2002), business (Cue, 1998) and economics (Simpson \& Oliver, 2006). Clickers have also been leveraged upon in the curricular implementation of different types of instructional formats, ranging from optional tutorials to formal standard lectures and cooperative learning through peer collaboration (Nichol \& Boyle, 2003). 


\section{Clickers as questionings aids in class}

The efficacy of questioning and interaction is reduced in proportion to an increase in classroom size. This is largely due to the difficulty faced by the lecturer in effectively managing interactions in large classrooms and the natural tendency of students to feel shy in speaking up publicly for fear of peer disapproval or embarrassment (Cadwell, 2007). These constraints can be addressed by clickers since clickers allow for students' responses to questions to be anonymously collated, accurately tallied and quickly displayed.

Clickers-supported questioning could also help reveal student misunderstandings and allow for prompt remediation to be done by lecturers (Wood, 2004). Besides correcting student misconceptions as part of formative assessment, by gauging student responses to posed questions, lecturers are also able to responsively modify subsequent directions of instruction to best align them with current levels of student conceptual understanding (Caldwell, 2007). In short, clickers can offer constructive feedback to both students and teachers and enable students to become more active participants rather than be peripheral observers in the classroom (Beekes, 2006).

\section{Clickers as formative assessment tools}

A number of empirical studies have been conducted to compare courses that have used clickers against those that have used other methods of instruction. These studies have established that one of the reasons for improved student performance is due to the pedagogical affordance of clickers in offering formative assessment (MacArthur, 2010). Poulis, Massen, Robens and Gilbert (1998) collected data over a 13 year period in chemistry, physics, and various engineering courses and found that when clickers were used $(\mathrm{N}=2550)$, the pass rate was $85 \%$, and when clickers were not used $(\mathrm{N}=$ 2841), the pass rate was $60 \%$. Hall, Collier, Thomas and Hilgers (2005) observed an improvement in student grades when clickers were used in a high enrolment general chemistry course $(\mathrm{N}=600)$. They attributed this improvement to formative assessment, as clickers were used primarily as a quiz to measure student preparation at the start of each class. However, there have been some studies to the contrary as well. Kennedy and Cutts (2005) analysed frequency and correctness of student responses in a computer science course and were unable to find evidence for increased learning due to formative assessment provided by clickers. Paschal (2002) conducted a comparison of courses with and without use of clickers. The experimental group was given in-class questions using clickers as well as quizzes on reading assignments whereas the control group did not have in-class questions or reading quizzes but had to complete homework assignments. The experimental group did not perform statistically significantly better than the control group.

\section{Clickers in promoting interactive engagement in class}

Mazur (1997) found significant gains from pre-test to post-test scores for physics students using clicker technology over those who did not. Mazur attributed this gain to the interactive pedagogy made possible by clickers rather than the technology itself. Reay, Bao, Warnakulasooriya and Baugh (2005) used a three-step sequence that included interactive engagement of students through the use of clickers. Students using clickers did better on exam questions covering the same material than those taught the material using traditional methods. One of the powerful features of clickers 
that promotes greater learning interactivity and engagement in clicker-enabled classrooms is the ability to provide instantaneous feedback during teaching. Boyle and Nicol (2003) reported in their study that students felt most engaged either when they were discussing topics with their peers or when immediate feedback was presented to the class. Yourstone, Kray and Albaum (2008) presented evidence from their design experiment study involving 190 undergraduate students that the immediacy of feedback provided by clickers, and subsequent discussions based upon such feedback, helped students who used clickers to obtain significantly higher performance test scores compared with their peers who did not use clickers.

\section{Other pedagogical uses of clickers}

Many lecturers have adopted clicker technology to compensate for the linear teaching and surface, passive learning prevalent in traditional lectures (Caldwell, 2007). Some institutions have adopted clickers in the hope of stemming high attrition rates in the sciences by making lessons more interactive and less impersonal (Burnstein \& Lederman, 2001). Clickers have been reported to be helpful in sustaining attention and breaking up contiguous content. Kay and LeSage (2009) reviewed the benefits using clickers based on 67 peer-reviewed papers spanning over a seven-year period from 2000 to 2007. Some of the benefits included positive student attitudes towards clickers, increased student attention, higher interest and engagement levels during classes (Kay \& LeSage, 2007). Using clickers to emphasise key concepts at the beginning of the class will be useful in checking understanding, and enable students to focus and settle down at the start of the class (Elliot, 2003). Middendorf and Kalish (1996) aver that periodic breaks, which clicker questions can provide, may help relieve student fatigue and "restart the attention clock".

\section{Research methods}

\section{Research design}

A non-experimental, predominantly quantitative or fixed research design (Robson, 1993) was adopted for the purpose of conducting this study. However, qualitative research methods in the form of observations and anecdotal interviews/talks were used sparingly where necessary to triangulate findings and strengthen conclusions drawn from the quantitative data analysis. The quantitative research approach was implemented by administering a constructed survey instrument and since surveys can be limited in offering in depth details of the research phenomena being investigated, the qualitative methods were meant to supplement the quantitative findings and offer deeper, richer insights. The informal interviews/talks were conducted with a handful of students who were conveniently available to the interviewer at the end of the lessons for short casual chats.

\section{Sample participants and size}

An open invitation to participate in the research study was sent to all academic staff who have used clickers in their classes. Lecturers teaching twelve classes from the disciplinary schools of Engineering, Humanities and Social Sciences and Biological Sciences responded to the invitation in the affirmative and volunteered to participate in the study. The spread across different disciplinary fields ensured a good measure of 
population representativeness. A total of 640 students from these twelve classes were involved in the study. These students were requested to provide their inputs to the question items in a clicker (audience responses system) facilitated survey.

\section{Survey instrument}

A survey consisting of nine items crafted by the researcher in consultation with the project-lead of the clicker initiative was administered to students participating in the study. The nine close-ended items were designed to solicit students' views on the effectiveness of clicker technology as an instructional and diagnostic assessment tool. Students' perspectives on how clickers have influenced the affective domain of their learning were also elicited in the survey. It was hoped that the survey would provide insights on whether the introduction of clickers has changed the nature of learning in the classroom. The number of items in the survey was limited to nine so as keep the survey succinct and minimise survey fatigue, in order to attract a higher participation rate amongst students.

\section{Data collection procedures}

The survey questions were displayed on the front projection screen at the beginning of the classes that had agreed to participate in the study. In responding to the nine items in the survey, student participants were encouraged to carefully consider the options and honestly select their choices. Students were instructed to send their responses by keying them using their clickers so that the data can be captured via the clicker system and easily tabulated for analysis. The total number of respondents for each of the survey items varied since many students streamed in late for their classes or chose not to respond to some of the items - an occurrence that was beyond the control of the researcher and lecturers. The response scores collected for each class were aggregated for the individual items and the accumulated data was then statistically analysed for meaningful research findings.

\section{Findings and discussions}

Reliability is the consistency of a set of measurements or constructs in a measuring instrument. Reliability is inversely related to random error (Meeker \& Escobar, 1998). The concept of reliability considers whether the obtained responses are a stable indication of the students' views of the items in a particular instrument. One form of reliability measure commonly used and developed by Kuder and Richardson (1937) is the internal consistency method. The Cronbach's coefficient alpha is a popular internal consistency reliability index. The internal consistency reliability of the Likert scale items 3, 4, 6, 7, 8 and 9 in the administered survey was assessed using the Cronbach alpha technique in SPSS and produced alpha $=0.703$ which was acceptable for a perception scale examining the pedagogical utility of clicker technology.

Validity refers to whether the items in the survey instrument measure what they had set out to measure (Burns, 2000). A 'construct' is a quality which has been suggested to explain aspects of human behavior. Construct validity can be ascertained through a variety of kinds of indirect evidence - for example, the items in a measuring instrument must be internally consistent in showing agreement that they are measuring the same qualities (Burns, 2000). In the context of the study described in this paper, a high alpha coefficient value was obtained for internal consistency, thus evidencing good construct validity. 
Content or face validity is an indication as to whether the items measure what the researcher wishes to measure. It is the representativeness or sampling adequacy of the content of a measuring instrument (Burns, 2000). To ensure content validity of the survey administered in this study, the researcher developed the items in the survey in close cooperation with the project-leader of NTU's clicker initiative, who has been involved in this project with the university for a few years and had thus gained extensive experience in clicker-supported pedagogy. His inputs and advice were regularly sought throughout the period of implementation of this study to ensure that the study set out to achieve its intended goals. In addition, the items in the survey were carefully and simply worded to ensure that there would be little ambiguity in participants' understanding of the information each item was attempting to elicit from them - this also helped to ensure a high degree of content validity.

Table 1: Survey responses

\begin{tabular}{|c|c|c|c|c|}
\hline \multirow{2}{*}{\multicolumn{3}{|c|}{ Survey items }} & \multicolumn{2}{|c|}{ Responses } \\
\hline & & & Frequency & Percentage \\
\hline 1. & \multirow[t]{4}{*}{ The clickers are used in my } & Lectures & 176 & 28.2 \\
\hline & & Tutorials / Seminars & 122 & 19.6 \\
\hline & & Both & 17 & 2.7 \\
\hline & & Neither & 309 & 49.5 \\
\hline \multirow[t]{4}{*}{2} & \multirow{4}{*}{$\begin{array}{l}\text { In this course, on average, clickers } \\
\text { are used _times within each } \\
\text { class. }\end{array}$} & $0-2$ & 238 & 37.8 \\
\hline & & 3-5 & 226 & 35.9 \\
\hline & & 6-8 & 48 & 7.6 \\
\hline & & $>8$ & 118 & 18.7 \\
\hline \multirow[t]{4}{*}{3.} & \multirow{4}{*}{$\begin{array}{l}\text { The use of clickers promotes } \\
\text { opportunities for peer interaction/s } \\
\text { with my fellow students. }\end{array}$} & Strongly disagree & 65 & 11.4 \\
\hline & & Disagree & 112 & 19.6 \\
\hline & & Agree & 250 & 43.9 \\
\hline & & Strongly agree & 143 & 25.1 \\
\hline \multirow[t]{4}{*}{4.} & \multirow{4}{*}{$\begin{array}{l}\text { The use of clickers has increased my } \\
\text { opportunities to interact with my } \\
\text { lecturer during lessons. }\end{array}$} & Strongly disagree & 60 & 10.0 \\
\hline & & Disagree & 131 & 21.9 \\
\hline & & Agree & 318 & 53.2 \\
\hline & & Strongly agree & 89 & 14.9 \\
\hline \multirow[t]{2}{*}{5.} & \multirow{2}{*}{$\begin{array}{l}\text { Clickers have been used to check } \\
\text { my understanding of content. }\end{array}$} & Yes & 517 & 84.6 \\
\hline & & No & 94 & 15.4 \\
\hline \multirow[t]{4}{*}{6.} & \multirow{4}{*}{$\begin{array}{l}\text { The use of clickers has increased my } \\
\text { motivation to attend class. }\end{array}$} & Strongly disagree & 125 & 20.1 \\
\hline & & Disagree & 177 & 28.5 \\
\hline & & Agree & 203 & 32.7 \\
\hline & & Strongly agree & 116 & 18.7 \\
\hline \multirow[t]{4}{*}{7.} & \multirow{4}{*}{$\begin{array}{l}\text { The use of clickers has resulted in } \\
\text { my feeling that I am more engaged } \\
\text { with my learning. }\end{array}$} & Strongly disagree & 52 & 8.7 \\
\hline & & Disagree & 132 & 22.2 \\
\hline & & Agree & 348 & 58.4 \\
\hline & & Strongly agree & 64 & 10.7 \\
\hline \multirow[t]{4}{*}{8.} & \multirow{4}{*}{$\begin{array}{l}\text { Clickers help me learn better } \\
\text { because of the immediate feedback I } \\
\text { get during lessons. }\end{array}$} & Strongly disagree & 31 & 5.1 \\
\hline & & Disagree & 68 & 11.2 \\
\hline & & Agree & 378 & 62.1 \\
\hline & & Strongly agree & 132 & 21.6 \\
\hline \multirow[t]{4}{*}{9.} & \multirow{4}{*}{$\begin{array}{l}\text { Overall, the use of clickers has } \\
\text { improved the quality of my } \\
\text { learning experience in this course. }\end{array}$} & Strongly disagree & 38 & 6.5 \\
\hline & & Disagree & 89 & 15.2 \\
\hline & & Agree & 376 & 64.2 \\
\hline & & Strongly agree & 83 & 14.1 \\
\hline
\end{tabular}

External validity asks the question as to how well the results of the study can be generalised to the population or settings (Burns, 2000). In this study, the subjects involved came from a broad spread across the different schools (humanities, sciences 
and engineering) of NTU to ensure a good representativeness of NTU's large student population.

The survey results for each of the survey items are presented in Table 1 (the complete listing of survey items can be found in the Appendix).

Nearly $97 \%$ of student respondents provided the feedback that clickers have been used in their lectures and tutorials or both (item 1 in the survey). On average, the frequency of usage of clickers for each lesson (item 2) was reasonably high. Given the large scale of the rollout of the clicker initiative throughout the university within a limited span of time and the provision of, thus far, only basic technical training to faculty on the functional mechanisms of clickers, the extent of utility of clickers in teaching is definitely encouraging. It is hoped that with more structured training being planned for offering in the future, on effective pedagogical techniques associated with the use of clickers in the classroom, faculty will be oriented to a wider repertoire of effective strategies to better enable them to successfully incorporate clicker technology in their teaching. Exploring ways of embedding clickers in their teaching would encourage faculty to rethink their traditional teaching methods and adopt instructional practices that deliver curricular content in technology-supported innovative ways to meet the needs of NTU's 'digitally' driven learners. An anecdotal observation of some of the classes utilising clicker technology found students being actively involved in their learning and an increase in 'buzz' level of the classes.

About $70 \%$ of student respondents either agreed or strongly agreed with the statements in items 3 and 4 of the survey, noting the use of clickers in fostering a learning environment in their classrooms that is more interactive and collaborative in nature. Clickers increased opportunities for faculty-student and student-student interactions, particularly during lecture times which have traditionally been passive learning experiences and lecturer-directed. Application of clicker technology during class makes learning more personalised, as students' responses to posed questions provide cues to faculty on how to proceed with their teaching. Clickers offer a significant opportunity for faculty to capture shy voices and voices from the back of the class. Students who might otherwise not contribute to open class discussions, or who prefer to conform to popular opinions, are prompted to participate by providing their opinions on issues being discussed (Dangel \& Wang, 2008). Hake (1998) noted that in practice, interactive learning engagement methods have been shown to be twice as effective as traditional teacher- centric lectures. The benefits of clickers in engendering peer learning are significant since peer instructions have been found to be less threatening and enable learners, by virtue of their similar ages, language and commonly shared experiences to clear up each other's confusions, misunderstandings and misconceptions (Wood, 2004).

Overall, the opportunities offered by clickers in implementing interactive pedagogy during class time appear to have made students enjoy and participate in the lessons. During informal talks with some of the students who had responded negatively to the impact of application of clickers in promoting socially interactive learning environments, it was found that clicker devices of themselves did not influence the quality of interactions. It was the quality of teaching that mattered. This finding is in accord with a conclusion from the clicker literature: clicker technology, like most other technology, is not a panacea in and of itself in solving pedagogical conundrums (Jackson \& Trees, 2003; Wood, 2004; Parsons, 2005). In fact, Jackson and Trees (2003) 
concluded that there are few (if any) collections of good clicker questions available for most fields of educational study. Thus, workshops on designing good clicker questions and applying effective questioning/facilitation strategies were identified as important areas of training that need to be offered for faculty development to promote more effective use of clickers in teaching and learning.

About $84 \%$ averred that clickers have been used appropriately by faculty to check their understanding of content covered during classes (item 5 in the survey). This finding could be better understood by linking it to the survey item which solicited students' views on whether clickers enabled them to learn better due to the provision of immediate diagnostic feedback (item 8). About $84 \%$ of student participants responded with a strongly agree or agree to item 8 of the survey on the ability of clickers to help them to learn better, due to the immediate feedback they get when data statistics is instantaneously generated and displayed on screen. This promptness in feedback facilitated better reinforcement of learning and allowed faculty to provide immediate remediation, where necessary, when misconceptions were identified. Being able to regularly monitor students' understanding during lesson time meant that faculty can now responsively manage instructional pathways - enabling teaching to be flexible, adaptive and customised. Anonymously gathering and projecting students' responses to questions via the clicker system allowed students to compare their understanding with that of their peers and gain mastery of relevant subject content matter. However, faculty need to take note that besides being prompt, feedback also has to be directive and specific to provide useful guidance for students to organise their own learning (Benson, Mattson \& Adler, 1995).

Analysing clickers' impact on the affective domain of learning, it was found that students were somewhat ambivalent about clickers' ability as a motivator to encourage them to attend classes (item 6 in survey). Though some studies such as Hanson's (2007) observed that students and faculty expressed a positive view of clicker systems in relation to perceived improvement in levels of attendance and motivation, we are unable to draw a similar conclusion based upon our data. This reinforces the notion that clickers, or for that matter, any type of technology is not of itself a 'magical bullet' to solve educational problems. The pedagogical ways in which technologies are embedded in the learning processes actually determine the success of an educational initiative. It is important for educators to be aware that the benefits of clickers in enhancing the quality of teaching do not happen automatically or immediately with the introduction of clickers within classroom contexts. Educators need to properly formulate their instructional goals and carefully plan for clicker questions in class discussions to attain those goals (Dangel \& Wang, 2008). About 69\% of the students responded to item 7 of the survey either strongly agreeing or agreeing that they felt they are better engaged in their learning with the use of clickers. This is an encouraging sign since students have acknowledged the positive impact of clickers in increasing engagement with their learning during class time.

Overall, about $74 \%$ of students either agreed or strongly agreed that clickers as an educational tool have the capacity to bring about improved learning (item 9 in survey). One student casually commented thus: "Clickers have kept us on our toes. We have to be attentive in class and be involved during discussions to be able to respond to questions when our lecturers pose them. This becomes particularly relevant when the lecturer decides to have an unannounced quiz in class to test our understanding on what we have learnt thus far." 


\section{Conclusions}

Overall, students felt that the use of clickers has improved the quality of their learning experiences. This study revealed that clicker technology offers good promise in innovating teaching approaches and making learning more meaningful. Clickers can be used adaptively in a variety of disciplinary fields and academic levels of study to improve students' engagement with the learning process. Increasing students' engagement enables learning to be more customised, particularly in large classroom settings, and can optimise learning gains. Clickers are also an efficacious educational tool to promote interactive and collaborative learning in class. Clickers have great potential in fostering learning ecologies that are more dialogic and student-directed in nature. However, to be able to achieve this, faculty would need to adopt sound clicker technology-supported pedagogical principles.

Some of these principles include asking the right types of formative and summative questions at appropriate junctures of the lessons, to check for content understanding, resolve misconceptions and generate new ideas (Pritchard, 2006). More research studies are being planned as a follow-up to this preliminary study, to explore best practices and case studies of effective pedagogical uses of clickers in NTU. Such exemplars could then help to promote the widespread diffusion and integration of clicker technology within curricular implementation. The instructional contexts, learning styles and questioning techniques that are best suited to the use of clickers also need to be investigated. In short, the findings of this study do encourage a scaling up of the application of clicker technology in instructional approaches in support of NTU's paradigm shift: teach less and learn more.

\section{References}

Barber, M. \& Njus, D. (2007). Clicker evolution: Seeking intelligent design. CBE-Life Science Education, 6(1), 1-8. http:/ / lifescied.org/ content/6/1/1.full.pdf

Beekes, W. (2006). The "millionaire" method for encouraging participation. Active Learning in Higher Education, 7(1), 25-36. http:/ / dx.doi.org/10.1177/1469787406061143

Benson, D., Mattson, L. \& Adler, L. (1995). Prompt feedback. In S. R. Hatfield (Ed), The seven principles in action: Improving undergraduate education (pp. 55-66). Bolton, MA: Anker Publishing Co.

Boyle, J. T. \& Nicol, D. J. (2003). Using classroom communication systems to support interaction and discussion in large class settings. Association for Learning Technology Journal, 11(3), 43-57. http: / / repository.alt.ac.uk/413/

Burns, R. B. (2000). Introduction to research methods (4th ed.). London : SAGE Publication.

Burnstein, R. A. \& Lederman, L. (2001). Using wireless keypads in lecture classes. Physics Teacher, 29, 8-11. http: / / citeseerx.ist.psu.edu / viewdoc/ download?doi=10.1.1.112.3323\& rep $=$ rep1\&type $=$ pdf

Caldwell, J. E. (2007). Clickers in the large classroom: Current research and best-practice tips. CBE-Life Sciences Education, 6(1), 9-20. http:/ / lifescied.org/content/6/1/9.full.pdf + html

Campbell, J. \& Mayer, R. E. (2009). Questioning as an instructional method: Does it affect learning from lectures? Applied Cognitive Psychology, 23(6), 747-759. http:/ / dx.doi.org/10.1002/acp.1513 
Cue, N. (1998). A universal learning tool for classrooms? Paper presented in The First Quality in Teaching and Learning Conference (Hong Kong, SAR, China, December 10-12, 1998). http: / / celt.ust.hk/ files/ public/ nelsoncue.pdf

Dangel, H. L. \& Wang, C. X. (2008). Student response systems in higher education: Moving beyond linear teaching and surface learning. Journal of Educational Technology Development and Exchange, 1(1), 93-104. http:// www.sicet.org/journals/jetde/jetde08/ paper08.pdf

Draper, S. W. (2002). Evaluating effective use of PRS: Results of the evaluation of the use of PRS in Glasgow University. Glasgow University, Scotland. [viewed 14 Mar 2011] http:/ / www.psy.gla.ac.uk/ steve/ilig/papers/eval.pdf

Elliot, C. (2003). Using a personal response system in economics teaching. International Review of Economics Education, 1(1), 80-86. http:/ / www.economicsnetwork.ac.uk/iree/i1/ elliott.htm

Gan, C. L. (2011). Effective learning in classrooms of tomorrow at NTU. Singapore. Paper presented at the E-learning Asia Forum 2011 (Singapore, June 8, 2011). http:/ / elfasia.org/ elfa2011/download/presentation/Session\%201C_Gan\%20Chee\%20Lip.pdf

Hake, R. R. (1998). Interactive-engagement versus traditional methods: A six-thousand student survey of mechanics test data for introductory physics courses. American Journal of Physics, 66(1), 64-74. http:/ / web.mit.edu/rsi/www/2005/misc/minipaper/ papers/Hake.pdf

Hall, R. H., Collier, H. L., Thomas, M. L. \& Hilgers, M. G. (2005). A student response system for increasing engagement, motivation, and learning in high enrolment lectures. In Proceedings from the Eleventh Americas Conference on Information Systems (pp. 621-626). Omaha, NE: AMCIS.

Halloran, L. (1995). A comparison of two methods of teaching: Computer managed instruction and keypad questions versus traditional classroom lecture. Computers in Nursing, 13(6), 285288.

Hanson, C. R. (2007). An evaluation of a student response system used at Brigham Young University. Unpublished master's thesis. Brigham Young University, Utah. http: / / contentdm.lib.byu.edu/ETD/image/etd2127.pdf

Jackson, M. \& Trees, A. (2003). Clicker implementation and assessment. Boulder, CO: Information and Technology Services and Faculty Teaching Excellence Program, University of Colorado. http: / / comm.colorado.edu/ mjackson/ clickerreport.htm [viewed 24 Jan 2011, not found 4 Dec 2011]

Kay, R. H. \& LeSage, A. (2009). Examining the benefits and challenges of using audience response systems: A review of the literature. Computers $\mathcal{E}$ Education, 53(3), 819-827. http:/ / dx.doi.org/10.1016/j.compedu.2009.05.001

Kennedy, G. E. \& Cutts, Q. I. (2005). The association between students' use of an electronic voting system and their learning outcomes. Journal of Computer Assisted Learning, 21(4), $260-$ 268. http:/ / dx.doi.org/10.1111/j.1365-2729.2005.00133.x

Kuder, G. \& Richardson, M. (1937). The theory of the estimation of test reliability. Psychometrika, 2(3), 151-156. http: / / dx.doi.org/10.1007/BF02288391

Lin, Y.-C., Liu, T.-C. \& Chu, C.-C. (2011). Implementing clickers to assist learning in science lectures: The Clicker-Assisted Conceptual Change model. Australasian Journal of Educational Technology, 27(6), 979-996. http:/ / www.ascilite.org.au/ajet/ajet27/lin.html

MacArthur, J. R. (2010). Factors that promote success in large enrolment general chemistry courses taught with clickers. Unpublished doctoral dissertation, University of Northern Colorado, Greeley, Colorado.

http: / / adr.coalliance.org/cogru / fez/eserv/cogru:348/MacArthur_unco_0161N_10039.pdf

Mazur, E. (1997). Peer instruction: A user's manual. Upper Saddle River, NJ: Prentice Hall. 
Meeker, W. Q. \& Escobar, L. A. (1998). Statistical methods for reliability data. Hoboken, New Jersey: Wiley.

Middendorf, J. \& Kalish, A. (1996). The "change-up" in lectures. National Teaching and Learning Forum, 5(2), 1-5. http: / /www.ntlf.com/html/ pi/9601/article1.htm

Moreau, N. (2009). Do clickers open minds? Use of a questioning strategy in developmental mathematics. Unpublished doctoral dissertation, Capella University, Minneapolis, Minnesota. http: / /gradworks.umi.com/33/89/3389211.html

Nichol, D. J. \& Boyle, J. T. (2003). Peer instruction versus class-wide discussion in large classes: A comparison of two interaction methods in the wired classroom. Studies in Higher Education, 28(4), 457-473. http: / / dx.doi.org/10.1080/0307507032000122297

Parsons, C. V. (2005). Decision making in the process of differentiation. Learning $\mathcal{E}$ Leading with Technology, 33(1), 8-10. http:/ / business.highbeam.com/4240/article-1G1136162812 / decision-making-process-differentiation

Paschal, C. (2002). Formative assessment in physiology teaching using a wireless classroom communication system. Advances in Physiology Education, 26(4), 299-308. http: / / advan.physiology.org/ content/26/4/299.full

Penuel, W. R., Roschelle, J., Crawford, V., Shechtman, N. \& Abrahamson, L. (2004). Workshop report: Advancing research on the transformative potential of interactive pedagogies and classroom networks. Menlo Park: SRI International.

Poulis, J., Massen, C., Robens, E. \& Gilbert, M. (1998). Physics lecturing with audience paced feedback. American Journal of Physics, 66(5), 439-441. http:/ / dx.doi.org/10.1119/1.18883

Pritchard, D. (2006). The use of "clicker" technology to enhance the teaching/learning experience. C.A.L.T. E-learning enhancement grant 2006, University of Otago, New Zealand. http: / / hedc.otago.ac.nz/hedc/asd/Digital-Resources-for-yourTeaching/mainParagraphs/012/document/ClickersReport.pdf [viewed 13 Jan 2011]

Reay, N. W., Bao, L., Li, P., Warnakulasooriya, R. \& Baugh, G. (2005). Toward the effective use of voting machines in physics lectures. American Journal of Physics, 73, 554-558. http:// dx.doi.org/10.1119/1.1862638

Robson, C. (1993). Real-world research: A resource for social scientists and practitioner-researchers. Malden: Blackwell Publishing.

Simpson, V. \& Oliver, M. (2006). Using electronic voting systems for lectures then and now: A comparison of research and practice. Australasian Journal of Educational Technology, 23(2), 187208. http:/ / www.ascilite.org.au/ajet/ajet23/simpson.html

Yourstone, S. A., Kray, H. S. \& Albaum, G. (2008). Classroom questioning with immediate electronic response: Do clickers improve learning? Decision Sciences Journal of Innovative Education, 6(1), 75-88. http: / / dx.doi.org/10.1111/j.1540-4609.2007.00166.x

Wood, W. B. (2004). Clickers: A teaching gimmick that works. Developmental Cell, 7(6), 796-798. http:/ / www.colorado.edu/MCDB / MCDB6440/ClickersDevCellC.pdf

\section{Appendix: Survey questions}

1. The clickers are used in my

Lectures

Tutorials/Seminars

Neither

Both 
2. In this course, on average, clickers are used $0-2$

$$
\text { 3-5 }
$$

6-8

$>8$

3. The use of clickers promotes opportunities for peer interaction/s with my fellow students. Strongly disagree

Disagree

Agree

Strongly agree

4. The use of clickers has increased my opportunities to interact with my lecturer during lessons.

Strongly disagree

Disagree

Agree

Strongly agree

5. Clickers have been used to check my understanding of content.

Yes

No

6. The use of clickers has increased my motivation to attend class.

Strongly disagree

Disagree

Agree

Strongly agree

7. The use of clickers has resulted in my feeling that I am more engaged with my learning. Strongly disagree

Disagree

Agree

Strongly agree

8. Clickers help me learn better because of the immediate feedback I get during lessons.

Strongly disagree

Disagree

Agree

Strongly agree

9. Overall, the use of clickers has improved the quality of my learning experience in this course. Strongly disagree

Disagree

Agree

Strongly agree

Author: Dr Kumar Laxman, Centre for Excellence in Learning and Teaching, Nanyang Technological University, Singapore. Email: haribol.kumar@gmail.com Web: http: / / sites.google.com/site/kumarlaxman108/

Please cite as: Laxman, K. (2011). A study on the adoption of clickers in higher education. In Hong, K. S. \& Lai, K. W. (Eds), ICT for accessible, effective and efficient higher education: Experiences of Southeast Asia. Australasian Journal of Educational Technology, 27(Special issue, 8), 1291-1303. http: / / www.ascilite.org.au/ajet/ajet27 / laxman.html 